\title{
Seasonal Influence on Pigment Production in Nine Species of Trees and Shrubs in Linares, Northeast of Mexico
}

\author{
Humberto Gonzalez Rodriguez ${ }^{1 *}$, Ratikanta Maiti ${ }^{1}$ and Aruna Kumari ${ }^{2}$ \\ ${ }^{1}$ Universidad Autonoma de Nuevo Leon, Facultad de Ciencias Forestales, Carr. Nac. No. 85 Km. 45, Linares, \\ Nuevo Leon (67700), México \\ ${ }^{2}$ Dept. of Plant physiology, PJTSAU, Agricultural College, Polasa, Jagtial, Karimnagar, Telengana State (505 529), India
}

\section{Article History}

Manuscript No. AR1369

Received in $10^{\text {th }}$ April, 2015

Received in revised form $28^{\text {th }}$ May, 2015

Accepted in final form $6^{\text {th }}$ June, 2015

\section{Correspondence to}

EE-mail: humberto.gonzalez@uanl.mx

\section{Keywords}

Native plant species, chlorophylls, carotenoids, variability, seasons

\begin{abstract}
Plant pigments play an important role in plant assimilatory systems and plant growth. Large variations were observed in the contents of chlorophyll (a and b, total chlorophyll) and also in carotenoids among the nine species of trees and shrubs. The species, Guiacum angustifolium and Diospyros palmeri did not show variation, while Helietta parviflora and Bernadia myricifolia and Leucophyllum frutescens showed decrease in chl a content in summer. Ebenopsis ebano, Eysenhardtia polystachya and Leucaena leucocephala showed increase in chl a during summer, whereas an increase in chl a content was observed in Bernadia myricifolia and Leucophyllum frutescens in winter. Helietta parviflora, Guiacum angustifolium, Ebenopsis ebano, Diospyros palmeri showed decrease in chl $\mathrm{b}$ in summer, but Leucophyllum frutescens followed by Bernardtia myricifolia showed a larger reduction in chl b in summer. The species Ebenopsis ebano, Diospyros palmeri, Bernardtia myricifolia, Leucophyllum frutescens showed an increase in chl b content in winter. With respect to carotenoid the species also showed variable responses in two seasons, winter and summer but Guiacum angustifolium and Sargentia gregii showed negligible increase, while Ebenopsis ebano, Diospyros palmeri and Leucaena leucocephala, showed an increase in carotenoid content in summer, while Helietta parviflora, Bernardtia myricifolia and Leucophyllum frutescens showed decline in carotenoid in summer. The proportion of $\mathrm{chl} \mathrm{a} / \mathrm{chl} \mathrm{b}$ showed variations in few species except Eysenhardtia polystachya and Bernadtia myricifolia (vey negligible) but all other species showed an increase. Therefore, Eysenhardtia polystachya and Bernadtia myricifolia could be considered to be well adapted in both winter and summer season which needs to be confirmed.
\end{abstract}

\section{Introduction}

Plant pigments play an important role in plant metabolism. Various leaf pigments such as chlorophyll, carotenoids, xanthophylls, flavonoids etc., play important roles in the physiological performance of the plants, which can be related to varying leaf structural characteristics. Often, the presence of these acts as indices for protection. Chlorophyll and carotenoids play an important role in photosynthetic process in higher plants. They play a vital role in capturing light energy, which is converted to chemical energy (Britton, 1995). Chlorophyll has capacity in absorbing radiant energy of sunlight into chemical energy of organic carbon through the process of photosynthesis (Sims and Ganon, 2002).

Carotenoids are natural fat-soluble pigments found in plants, algae and photosynthetic bacteria, where they also play a role in photosynthesis. In some non-photosynthetic bacteria, they may help in protective functions against damage by light and oxygen (Biswel, 1995; Gitelson et al., 1999). Animals appear not to have capacity to synthesize carotenoids and may incorporate carotenoids from their diets. In animals carotenoids impart bright coloration and serve as antioxidants and a source for vitamin A activity (Brotton, 1995). Besides, carotenoids develop important functions in plant in plant reproduction through their role in attracting pollinators and seed dispersal (Yeum and Russel, 2002). Uvaille Saucedo et al. (2008) studied seasonal trends of chlorophyll $\mathrm{a}$ and $\mathrm{b}$ and carotenoids in native shrubs of Northeastern Mexico. They reported that all these pigments were significantly different between years and also among species thereby, exhibiting the influence of climates on 
pigment production in plants.

Chlorophyll and carotenoids are responsible to absorb light energy and transfer it to the photosynthetic apparatus in chloroplast for the production of photosynthates and finally to biomass production in plants. Therefore, the estimation of leaf pigment content serves as a valuable tool to understand the physiological and biochemical functions of leaves (Sims and Ganon, 2002). Native shrubs and trees in semiarid region of Northeastern Mexico serve as important resources for varied range of ruminants and white tailed deer (Ramirez-Lozano, 2015). They also provide high quality fuel and timber for fencing and construction (Reid et al., 1990; Fullbright et al., 1991) but the growth of these species is affected by climatic conditions probably causing differences in the production of the photosynthetic pigments. The objective of the present study is to determine the differential response of few native trees and shrubs in the pigment contents in winter and summer seasons.

\section{Materials and Methods}

This study was undertaken in winter (February, 2015) and summer (June, 2015) at the experimental station of Facultad de Ciencias Forestales, Universidad Autonoma de Nuevo Leon, located in the municipality of Linares $\left(24^{\circ} 47^{\prime} \mathrm{N} .99^{\circ} 32^{\prime} \mathrm{W}\right)$, at elevation of $350 \mathrm{~m}$. The climate is subtropical or semiarid with warm summer, monthly mean air temperature vary from $14.7^{\circ} \mathrm{C}$ in January to $23^{\circ} \mathrm{C}$ in August, although during summer the temperature goes up-to $45^{\circ} \mathrm{C}$. Average annual precipitation is around $805 \mathrm{~mm}$ with a bimodal distribution. The dominant type of vegetation is the Tamaulipan Thornscrub or subtropical Thorncrub wood land (SPP-INEGI, 1986). The dominant soil is deep, dark gray, lime-gray, Vertisol with montmorillonite, which shrink and swell remarkably in response to change in moisture content.

The following nine species are included in this study for analysis of plant pigments (Table 1). Determinations of pigments were done in two seasons, winter (February, 2015) and summer (June, 2015) for this study. Four samples of leaf tissue ( $1.0 \mathrm{~g}$ of fresh weight) of each plant species were used for analysis. The chlorophyll $\mathrm{a}$ and $\mathrm{b}$ and carotenoids were extracted in $80 \%$ (v.v) aqueous acetone and vacuum filtered through a Whatman No.1 filter paper. Pigment measurements were determined spectrophotometrically using a PerkinElmer Spectrophotometer (Model Lamda 18). Absorbance of chlorophyll a, Chlorophyll b and carotenoid extracts were determined at wavelengths of 669,645 and $470 \mathrm{~nm}$ respectively. Carotenoid ( $\mathrm{mg} \mathrm{g}^{-1}$ dry weight) of pigments was calculated by equations of Lichtenthaler Wellbaum, 1983).

\begin{tabular}{|c|c|c|c|}
\hline \multicolumn{4}{|c|}{ Table 1: Plants under study } \\
\hline $\begin{array}{l}\text { Common } \\
\text { name }\end{array}$ & Scientific name & Family & Type \\
\hline Barreta & Helietta parvifolia & Rutaceae & Arbusto \\
\hline $\begin{array}{l}\text { Chapote } \\
\text { amarillo }\end{array}$ & Sargentia gregii & Rutaceae & Arborea \\
\hline Guayacan & $\begin{array}{c}\text { Guaiacum } \\
\text { angustifolium }\end{array}$ & $\begin{array}{c}\text { Zygophyl- } \\
\text { laceae }\end{array}$ & Arbustiva \\
\hline ebano & Ebenopsis ebano & Fabaceae & Arborea \\
\hline $\begin{array}{l}\text { Chapote } \\
\text { manzano }\end{array}$ & Diospyros palmeri & Ebenaceae & Arborea \\
\hline Leucaena & $\begin{array}{c}\text { Leucaena } \\
\text { leucocephala }\end{array}$ & Fabaceae & Arborea \\
\hline Vara dulce & $\begin{array}{c}\text { Eysenhardtia } \\
\text { polystachya }\end{array}$ & Fabaceae & Arbustiva \\
\hline $\begin{array}{l}\text { Oreja } \\
\text { raton }\end{array}$ & $\begin{array}{c}\text { Bernardia } \\
\text { myricifolia }\end{array}$ & $\begin{array}{c}\text { Euphrobi- } \\
\text { aceae }\end{array}$ & Arbustiva \\
\hline Cenizo & $\begin{array}{l}\text { Leucophyllum } \\
\text { frutescens }\end{array}$ & $\begin{array}{l}\text { Scrophula- } \\
\text { riaceae }\end{array}$ & Arbustiva \\
\hline
\end{tabular}

\section{Results and Discussion}

In the following figures (Figure 1-6) are depicted the variations in the contents of different pigments between seasons and among the species. It is observed that the species studied showed variable response to seasons with respect to the contents chlorophyll a except two species. The species, Guiacum angustifolium and Diospyros palmeri did not show variation, while Helietta parviflora and Bernadia myricifolia and Leucophyllum frutescens showed decrease in chl a content in summer. On the otherhand, Ebenopsis ebano, Eysenhardtia polystachya and Leucaena Leucocephala showed increase in chl a during summer, whereas an increase in chl a content was observed in Bernadia myricifolia and Leucophyllum frutescens in winter. In winter chl a ranged from around $0.2 \mathrm{mg}$ to $2 \mathrm{mg}$ while in summer it ranged from around $0.4 \mathrm{mg}$ to $1.8 \mathrm{mg}$.

With respect to chl b, Sargentia gregii, Leucaena leucocephala showed negligible variation between seasons. On the other hand, other species such as Helietta parviflora, Guiacum angustifolium, Ebenopsis ebano, Diospyros palmeri showed decrease in chl b in summer, but Leucophyllum frutescens followed by Bernardtia myricifolia showed a larger reduction in chl b in summer, while Eysenhardtia polystachya showed a slight increase in summer. The species Ebenopsis ebano, Diospyros palmeri, Bernardtia myricifolia, Leucophyllum frutescens showed an increase in chl b content in winter. In winter chl b varied from 0.2 to $0.5 \mathrm{mg}$, while in summer it varied from 0.1 to $0.4 \mathrm{mg}$. 

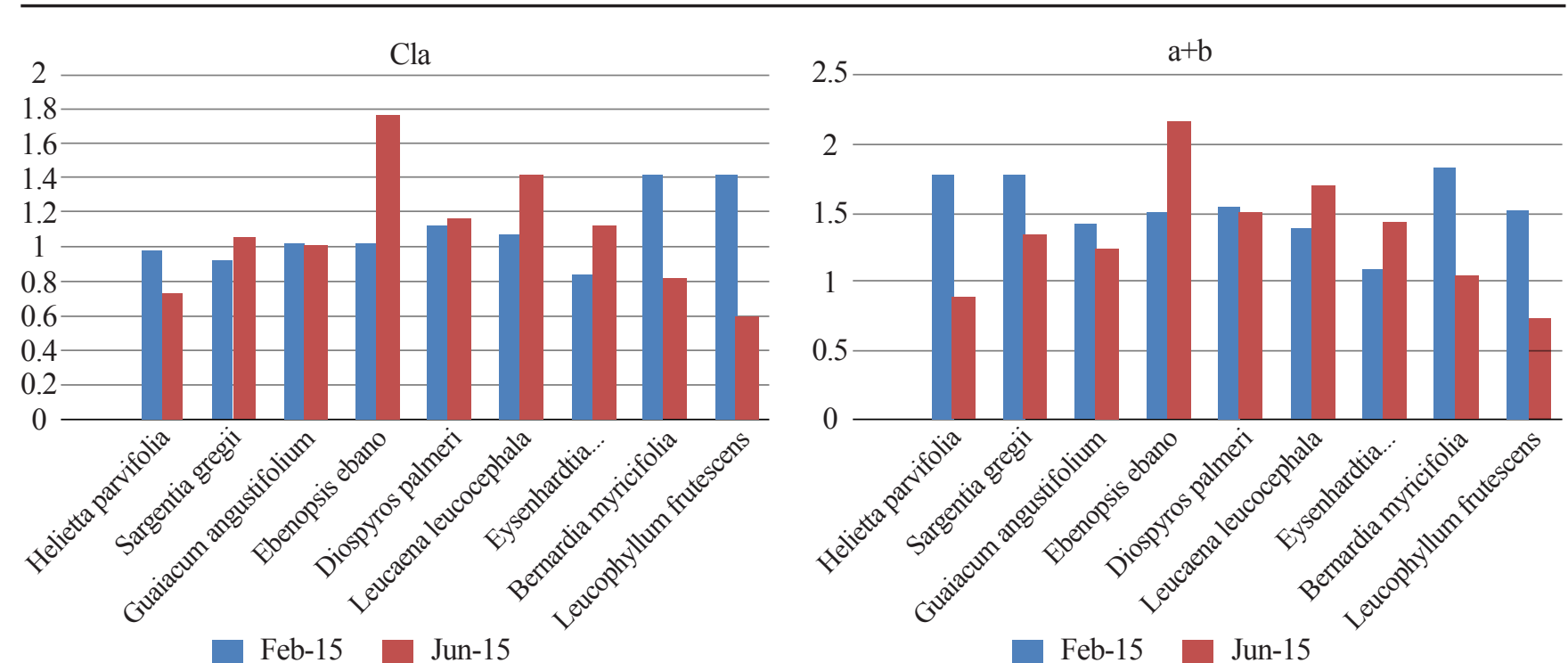

Feb-15 Jun-15

$\mathrm{Clb}$

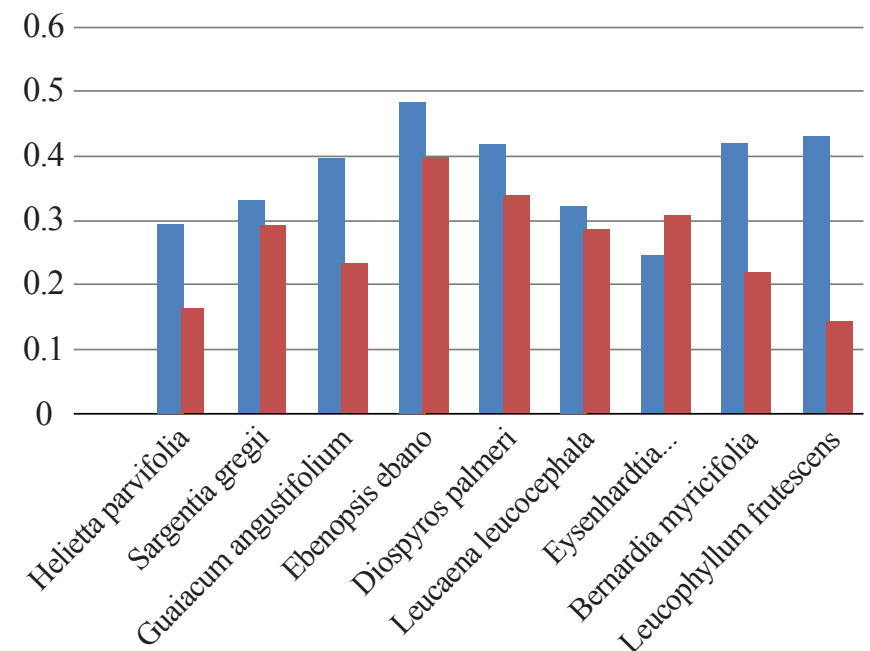

Feb-15 Jun-15

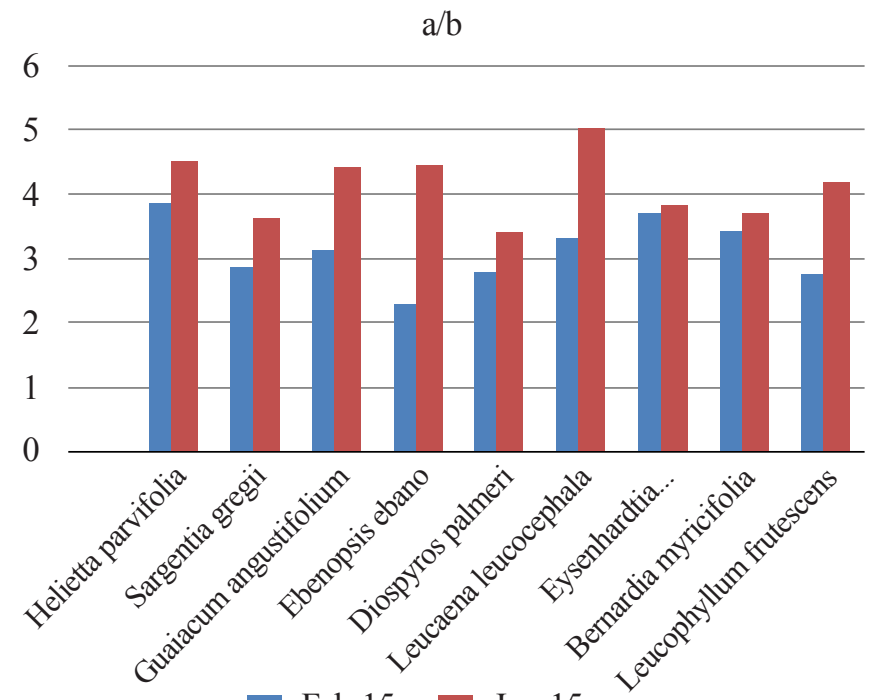

Feb-15 Jun-15

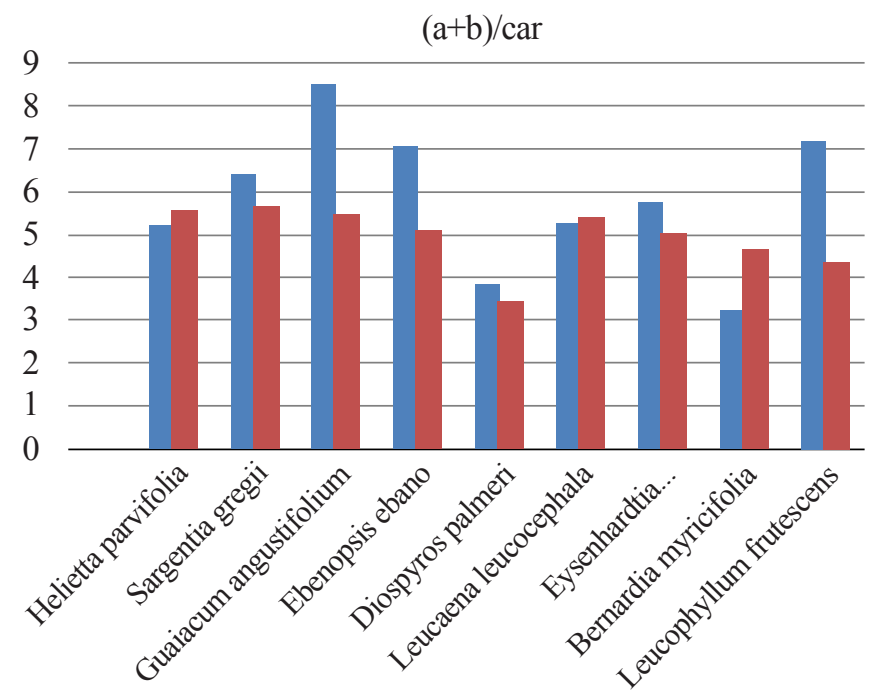

Feb-15 Jun-15

Figure 1-6: Different pigments between seasons and among the species 
With respect to carotenoid the species also showed variable responses in two seasons, winter and summer but Guiacum angustifolium and Sargentia gregii showed negligible increase, while Ebenopsis ebano, Diospyros palmeri and Leucaena leucocephala, showed an increase in carotenoid content in summer. On the other hand, Helietta parviflora, Bernardtia myricifolia and Leucophyllum frutescens showed decline in carotenoid in summer. The species Bernardtia myricifolia exhibited a large increase in carotenoid content in winter compared to other species. In winter season the carotenoid contents ranged from around 0.3 to $0.5 \mathrm{mg}$, while in summer they ranged around 0.2 to $0.4 \mathrm{mg}$.

The proportion of $\mathrm{chl} \mathrm{a} / \mathrm{chl} \mathrm{b}$ showed variations in few species except Eysenhardtia polystachya and Bernadtia myricifolia (vey negligible) but all other species showed an increase, indicating the favourable effect of higher temperature during summer season. This could have an effect on the physiological function of the leaf and photosynthesis. Therefore, Eysenhardtia polystachya and Bernadtia myricifolia could be considered to be well adapted in both winter and summer season which needs to be confirmed.

With respect to total chlorophyll (chla + chl b) the species also showed variable responses. Sargentia greggi, Guiacum angustifolium, Diospyros palmeri showed negligible variation, while Ebenopsis ebano, Leucaena leucocephala, and Eysenhardtia polystachya showed an increase in total chlorophyll content in summer. On the other hand, Helietta parviflora, Leucophyllum frutescens, and Bernadtia myricifolia showed decline in total chlorophyll content in summer and an increase in winter. In winter, the total chlorophyll ranged from around $1 \mathrm{mg}$ to about to $2 \mathrm{mg}$ while in summer it ranged from around 0.5 to more than $2 \mathrm{mg}$.

Further, it is observe that there is also a large variation among the species and seasons with respect to the total chlorophyll and carotenoid ratios. Negligible variation was found in Helietta parviflora, Leucaena leucocephala, while a higher chlorophyll to carotenoid ratio was seen in Guaicum angustifolium, Ebenopsis ebano, Leucophyllum frutescens, Sargentia gregii and Eysenhardtia polystachya in winter. The species Bernadtia myricifolia exhibited a higher ratio of total chlorophyll to carotenoid in summer, indicating its higher efficiency of photosynthesis and ability to combat high temperature effects. The efficiency of this species need to be confirmed through further research findings.

It is observed that in all the variables viz., Chlorophyll a, Chlorophyll b, Carotenoids, Chlorophyll $(\mathrm{a}+\mathrm{b})$ and Chlorophyll to Carotenoids ratio showed highly significant differences among the species studied.

In the context of the results, it may be interpreted that the species showed variations in various pigment contents in both winter (February, 2015) and Summer (June, 2015). In few of these tree species the pigment contents remained less stable. In few other species there was a decline or an increase. These variations in pigment contents could have direct or indirect effect on photosynthetic capacity and the productivity of the species studied which need to be confirmed in future study. It may be mentioned here that at the time of collection of leaf samples in February the temperature ranged from 2 to 3 degree, but few species such as Sargentia gregii and Guiacum angustifolium did not show decline in pigment contents as mentioned above showing tolerance to cold temperature (papers in press, IJBSM). Therefore, the climatic conditions and environments have an influence on pigment contents and probable photosynthetic capacity. It may be interpreted that the increase in chl-a in Ebenopsis ebano and Leucaena leucocephala and an increase in chl b in Eysenhardtia polystachya could be related to higher photosynthetic capacity in summer season. Our observations coincide with the findings of various authors who discussed the role of pigments in plant metabolism and plant productivity.

The results of the present study reveals that there was a remarkable variation in chlorophyll $\mathrm{a}$, chlorophyll $\mathrm{b}$, total chlorophyll and carotenoid contents, chl $\mathrm{a} / \mathrm{b}$ ratio, total chlorophyll to carotenoid ratio among the nine species and also between seasons studied. This finding confirms the importance of the species in their capacity in the production of each pigment to guide the photosynthetic process in leaves and its potential values which again depends on environmental conditions. Plant pigments may contribute to the ecosystem productivity, but it is influenced by drought and extreme temperature prevailing during winter and summer seasons (Gonzalez et al., 2000). It is also well known that the productivity of higher plants is mediated by photosynthesis in leaves and its adaptation through leaves (Valladares et al., 2000). The present study also shows the effects of several environmental factors in the production of plant pigments. It is well documented about the effects of these environmental factors by different authors such as high temperature in summer (Valladares et al., 1997; Gonzalez et al., 2004). Low temperature during winter and high temperature in summer reduce the pigment production there by affecting growth of the plant species. Under such conditions the production of photosynthates may be limited by temperature, leading to stomatal control and light energy damage. Similar to our observations in few species, the chlorophyll contents are affected by unfavourable temperature (Ottander et al., 1995) and also by the prevailing shade characteristics (Castrillo et al., 2000). There existed relationship between leaf pigment and spectral reflectance (Sims and Ganon, 2008). In the present study few species showed tolerance to low temperature in 
winter and high temperatures in summer showing stability of the pigment production.

Variations in chlorophyll contents between plants are reported to be related to leaf developments and senescence (Surfis, 2001). The chlorophyll content was higher in shade leaves, whereas carotenoid and non-photochemical quenching increased with light (Valladares et al., 1997). On the contrary, it has been found that decreased solar radiation increased chlorophyll content. The carotenoid components of sunleaves of plants revealed that sun leaves contained higher amount of components of xanthophylls cycles (Demning-Adams and Adams, 1992). The reduction of chlorophyll does not cause an adaptive response against the adverse condition in summer in Mediterranean summer which may be applicable in Northeastern Mexico (Kynerisis, 2000; Valladares et al., 2000). These could be related to varying leaf structural characteristics indices for the protection of leaf pigment content. Sims and Ganon (2002) studied relationship between leaf pigment content and spectral reflectance. Tatini et al. (2005) reported flavonoid present in the cuticle; thick cuticle and dense glandular trichomes protect Ligustrum vulgare at high solar radiation.

Various authors have reported the effects of environments on leaf pigments contents. Jiang et al. (2006) reported that the chlorophyll content and photosynthesis in young leaves were much higher than fully expanded leaves; leaf orientation, photorespiration and Xanthophyll cycle protect young seedlings against high irradiation in field. Deming-Adams and Adams (1992) analyzed carotenoid composition in sun and shaded plant with different forms. Gufrida et al. (2006) studied chlorophyll and chlorophyll derived components in pistachio kernels (Pistacia vera L.) and found 13 compounds. Gonzalez et al. (2001) studied environmental light effect on leaf on concentrations of photosynthetic pigments and chlorophyll fluorescence of Mahogany (Switinnia macrophylla Kung) and Tonka bean (Dipteroryx odorata). Chlorophyll contents were higher in shade leaves than in sun leaves. Kyparisis et al. (2006) reported seasonal fluctuations in photoprotective (xanthophylls cycle) and photoprotective (chlorophyll) capacity in eight Mediterranean plant species belonging to two different growth forms. Jeon et al. (2006) reported the effect of temperature on photosynthetic pigments, morphology and leaf gas exchange during ex vitro accumulation of micropropagated CAM.

\section{Conclusion}

The contribution of pigments and the role of climate on the physiological functions of leaf and its photosynthesis is well documented. The present study also shows the effects of several environmental factors in the production of plant pigments. There was a remarkable variation in chlorophyll a, chlorophyll b, total chlorophyll and carotenoid contents, $\mathrm{chl} \mathrm{a} / \mathrm{b}$ ratio, total chlorophyll to carotenoid ratio among the nine species and also between seasons studied. This finding confirms the importance of the species in their capacity in the production of each pigment to guide the photosynthetic process in leaves and its potential values which again depends on environmental conditions

\section{Acknowledgement}

The authors are highly thankful to Elsa Gonzalez and Eliud Avendano Gonzalez for dedicated hard work in the analysis of pigment content estimations of nine species of trees and shrubs and for statistical analysis to our full satisfaction.

\section{References}

Biswel, B., 1995. Carotenoid metabolism during leaf senescence and its control by light. J. Journal of Photochemistry and Photobiology B: Biology 30(1), 3-13.

Brotton, G., 1995. Structure and properties of carotenoids in relation to function. The FASEB Journal 9(5), 15511558 .

Castrillo, M., Vizcano, D., Moreno, E., Lotorraca, Z., 2000. Chlorophyll content in some cultivated and wild pecies of Famiaceae. Biologia Plantarum 44(3), 423-325.

Deming-Adams, B.Y.W.W., Adams, 1992. Carotenoid composition in sun and shaded plant with different forms. Plant Cell Environment 15(4), 411-419.

Fullbright, T.E., Reynold, J.P., Beason, S.L., Demaaris, S., 1991. Mineral contents of guijillo regrowth following cropping. Journal Range Management 44(5), 520-522.

Gitelson, A.A., Busechman, C., Hartman, P., Lichtenthaler, K., 1999. The chlorophyll fluorescence ratio as an accurate measure of the chlorophyll content in plants. Remote sensing Environment 69, 236-302.

Gonzalez, H., Cantu, S.L.S.L., Gonzalez, M.M.V., Jordan, Y L.W. R., 2000. Seasonal plant water relationships in Accacia berlenderi. Arid Soil Research Rehabilitation Journal 14(4), 343-357.

Gonzalez, J.F.C., Moreno, R.A., Vera, G., 2001. Concentrations of photosynthetic pigments and chlorophyll fluorescence of Mahogany and Tonka bean under two light conditions. Revista Brasileira de Fisiologia Vegetal (13(2), 149157.

Gonzalez, R.H., Cantu, S.L.S.L., Gonzalez, M.M.V., Ramirez, L.R.G., 2004. Plant water relations of thornscrub species in Northeastern Mexico. Journal of Arid Environments 58(4), 483-503.

Gufrida, D., Saitta, M., La Torre, L., Bonifact, L.Y., Dugo, G., 2006. Chlorophyll and chlorophyll derived components in Pistacho kernels (Pistacia vera L.) from Sicilly. 
International Journal of Food Science 18(3), 309.

Jeon, M.W., Ali, M.B., Hahn, E.J., Pack, K.Y., 2006. Photosynthetic pigments, morphology and leaf gas exchange during ex vitro acclimatization of micropropagated CAM Doritaenopsis plantlets under relative humidity and air temperature. Environmental and Experimental Botany 55, 183-194.

Jiang, C.D., Gao, H.Y., Zao, Q., Jiang, G.M., Li, L.H., 2006. Leaf orientation, photorespiration and Xanthophyll cycle protect young soybean leaves against high irradiation in field. Environmental and Experimental Botany 55, 87-96.

Kyparisis, A.P., Drilias, Maneteros, 2006. Seasonal fluctuations in photoprotective (xanthophylls cycle) and photoprotective (chlorophyll) capacity in eight Mediterranean plant species belonging to two different growth forms. Australian Journal of Plant Physiology 27(3), 205-212.

Lichtenthaler, H.K., Wellburn, A.R., 1983. Determinations of total carotenoids and chlorophylls a and b of leaf extracts in different solvents. Biochemical Society Transactions 11, 591-592.

Ljudimila, K., Rech, J., Johns, P., 2007. The roles of specific xanthophylls in light utilization. Planta 225, 423-439.

Ramirez-Lozano, R.G., 2015. Native shrubs: Edible Foliage for small ruminants. In: Maiti et. Al. (Eds.), Applied Botany, 165-180. Puspa Publishing House, Kolkata, India.

Reid, N.J., Marroquin, Y.P., Beyer-Minzel, 1990. Utilization of shrubs and trees for browseing, fuel wood and timber in Tamaulipan thornscrub in Northeastern Mexico.
Forest Ecology and Management 36(1), 61-73.

Sims, D.A., Ganon, J.Y.Y.A., 2002. Relationship between leaf pigment content and spectral reflection across a wide range of species, leaf surface structure and developmental stages. Remote sensing of Environment 61, 331-354.

SPP-INEGI. 1986. Sintesis Geografía del Estado del Nuevo Leon, Secretaria de Programacion y Presupuesto, Instituto Nacional de Geografía Estadística e Informacion, Mexico, D.F

Tatini, M., Guidi, L., Morassi-Benz, L., Pinelli, P., Remorini, D., Degl'Innocente, E., Giordano, C., Massai, R., Agati, G., 2005). On the role of flavonoid in the integrated mechanism of respin photoprotective (Xanthophyll cycle onse of Ligustrum vulgare at high solar radiation. New Phytologist 167, 457-470.

Uvaille Sauceda J.I., González Rodríguez H., Ramírez Lozano R.G., Cantú Silva I., Gomez Meza M.V. 2008. Seasonal trends of chlorophylls $a$ and $b$ and carotenoids in native trees and shrubs of northeastern Mexico. Journal of Biological Sciences 8(2), 258-267.

Valladares, F., Martinez-Ferri, E., Balaguer, L., Perez-Corona, E., Manrique, E., 2000. Low leaf-level response to light and nutrients in Mediterranean evergreen oaks: a conservative resource-use strategy? New Phytologist 148(1), 79-91.

Yeum, K.J., Russell, R.M., 2002. Carotenoid bioavailability and bioconversion. Annual Review of Nutrition 22(1), 483-504. 